\title{
Daudzfunkcionālas, modulāras un ilgtspējīgas būves piekrastes zonā
}

\author{
Andra Ulme ${ }^{1}$, Evita Bārbale ${ }^{2}$ \\ ${ }^{1,2}$ Dizaina tehnologiju institūts, Materiālzinātnes un lietišķās ķıimijas fakultāte, Rīgas Tehniskā universitāte
}

\begin{abstract}
Kopsavilkums. Šī raksta mērķis ir izpētīt esošo situāciju Latvijas teritorijas piekrastē sabiedrisko būvju jomā (labierīcību telpas, gēerbtuves, dušas telpas un tamlīdzīgi). Tiek atspoguḷoti rezultāti, kuri iegūti apsekojot Latvijas teritorijas piekrastes pašvaldības. Rakstā aplūkotas galvenās vadlīnijas vienota stila piekrastes būvju izveidei. Šādu būvju izvietošana Latvijas piekrastes pašvaldību teritorijās dotu iespēju sakārtot piekrastes zonu, padarīt to pieejamu sabiedrībai, radīt drošu, funkcionālu un estētisku vidi ikvienam.
\end{abstract}

Atslēgas vārdi: Laba dizaina principi, ekoloğiskums, energoefektivitāte, ilglaicība.

\section{IEVADS}

Latvijas Republikas jūras robežas kopgarums ir 494 km (1). Piekrastes pašvaldības piedāvā dažādas atpūtas iespējas pie jūras gan vietējiem iedzīvotajiem, gan iebraucējiem. Bieži atpūtas iespējas tiek piedāvātas pie vides objektiem un apskates vietām: bākām, kāpām, jūras klintīm u.c. Lai veidotu sakārtotu vidi, kas ir pieejama ikvienam, ir nepieciešama vienota sistēma, kuru, pielāgojot esošajai videi, var izmantot visas Latvijas jūras robežas garumā. Nepieciešams ievērot aizsargjoslu likumu, lai nepiel̦autu būvju un objektu izbūvi vietās, kur tas nav aţ̦auts, tādā veidā sakārtojot, nevis degradējot apkārtējo vidi (2).

Šajā zinātniskajā rakstā ir atspogulota informācija, kura iegūta maǵistra darba tapšanas procesā. Maǵistra darba tēma ir "Daudzfunkcionālas, modulāras un ilgtspējīgas būves piekrastes zonā" Maǵistra darba ietvaros, 2015. gada vasarā un ruden̄̄ tika apsekotas septiņas piekrastes pašvaldības un noskaidrota esošā situācija piekrastes būvju jomā.

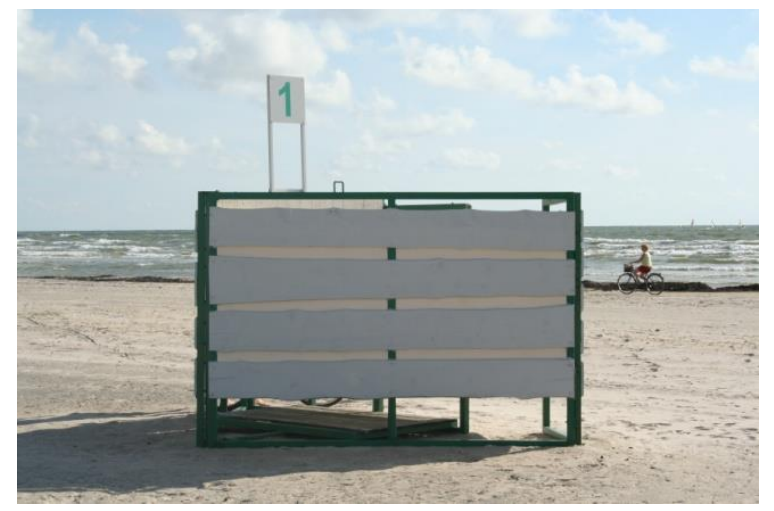

1. att. Liepājas pludmale (2015. gads).

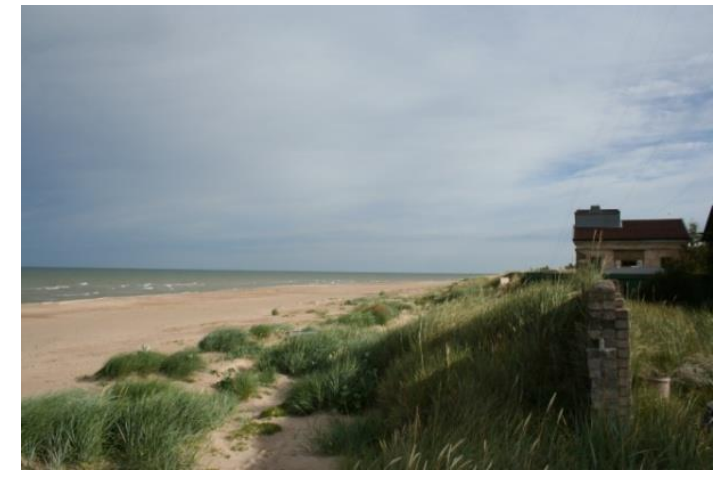

2. att. Sakas pagasta pludmale pie Akmeņraga bākas (2015. gads).

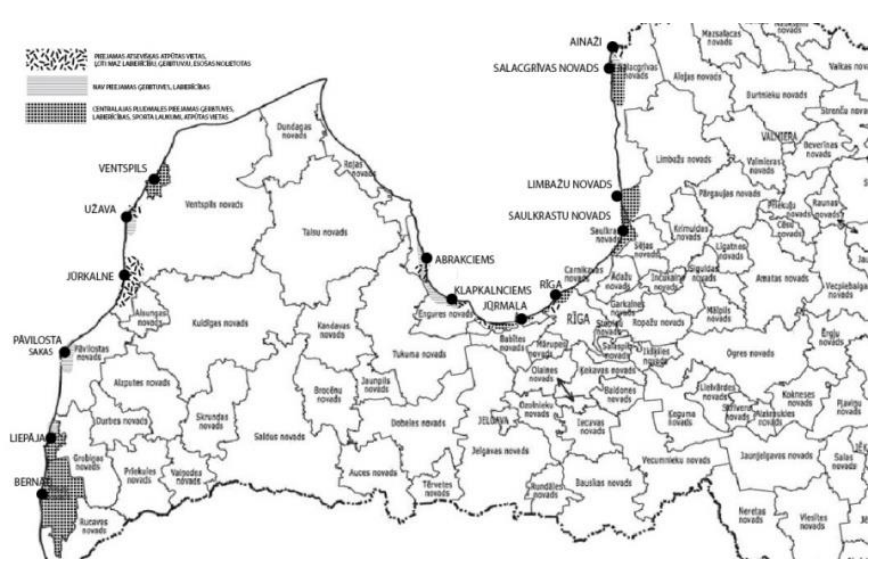

3. att. Apzinātās pašvaldības (1).

Piedāvājot sadarbības iespējas Latvijas piekrastes pašvaldībām, atsaucība bija zema, no 14 pašvaldībām (skat. 3. attēlu) interesi izrādīja tikai Salacgrīvas novada pašvaldība. Sadarbības piedāvājums tiks nosūtīts atkāroti, iekḷaujot jau detalizētāku informāciju, pievienojot pētījumu un aptauju rezultātus, tādējādi parādot problēmas aktualitāti, iedzīvotāju attieksmi un interesi par piekrastes joslu. 


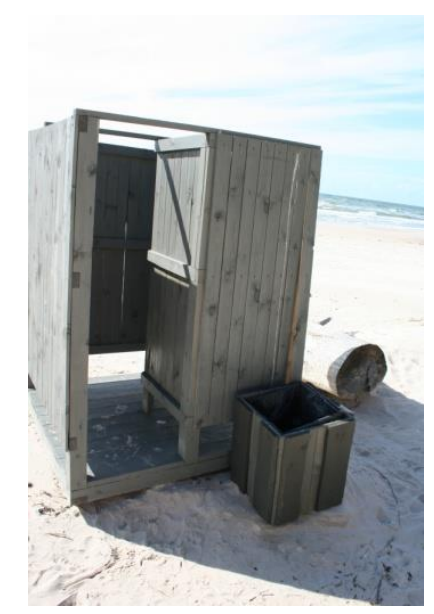

4. att. Bernātu pagasta pludmale (2015. gads).

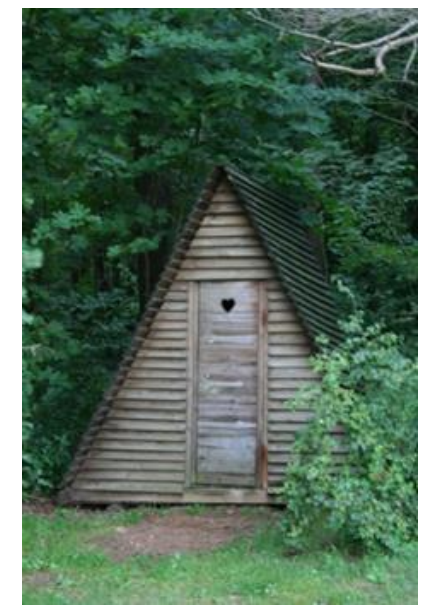

5. att. Jūrkalnes pagasta pludmale (2015. gads).

\section{ESOŠĀ SITUĀCIJA}

Tika apzinātas vairākas piekrastes pašvaldības (skat. 3. attēlu) Kurzemē: Liepājas centra pludmalē (skat. 1. attēlu) un Nīcas pagasta Bernātos (skat. 4. att.), Pāvilostā, Pāvilostas novada Sakas pagastā pie Akmeņraga bākas (skat. 2. attēlu), Ventspils novada Jūrkalnes pagastā (skat. 4. attēlu), Ventspils novada Užavas pagastā pie Užavas bākas, Ventspils centra pludmalē, Abrakciemā, Klapkalnciemā, kā arī Jūrmalā un Rīgā. Vidzemē: Saulkrastu novadā, Limbažu novadā, Salacgrīvas novadā, Ainažos (skat. 7.un 8. attēlu).

Iepazīstoties ar esošo situāciju rodas secinājumi, ka apdzīvotākās pilsētas, piemēram, Liepāja un Ventspils ir labiekārtojušas savas piekrastes zonas, izveidojot plašas atpūtas iespējas, gan mazo arhitektūras formu, gan sporta laukumu aktivitāšu realizācijai. Arī Saulkrasti, Salacgrīva un Rīga, kā arī Latvijas kūrortpilsēta Jūrmala ir pārdomāti veidojušas savas piekrastes zonas, lai gan vietējie iedzīvotāji, gan iebraucēji varētu atpūsties, nodarboties ar sportiskām aktivitātēm, pavadīt laiku pie ūdens.

Tomēr katrā no minētajām pilsētām piekrastes būves ir atšķirīgas. Skatoties no malas un salīdzinot visas iepazītās teritorijas, neveidojas vienots kopskats. Būves ir dažāda izmēra, dažādās, nereti košās krāsās, un ne vienmēr krāsas klājums ir vizuāli pievilcīgs, nenolobījies un tml. Atsevišksas būves ir nestabilas, ar dal̦ēji sabojātu vai nolietotu konstrukciju, tās elementiem, kas ir nedroši gan pieaugušajiem, gan bērniem.

Pavisam neliels ir labierīcību, geērbtuvju, soliṇu, nojumju skaits mazo pagastu piejūras teritorijās (skat. 4., 5., 9. attēlu). Pagastos ir neliels iedzīvotāju skaits, tomēr atpūtnieki nereti iegriežas, lai apskatītu kādu dabas vai vides objektu, piemēram, bāku, (skat. 2. att.) vai atpūstos pludmalē un pastaigātu gar jūras piekrasti.
Izvēloties gadalaiku, kurā apcel̦ot Latvijas piekrasti, tika izvirzīts kritērijs - sezonalitāte. Vasarā nereti pludmalēs ir izvietotas papildus labierīcības un mazās arhitektūras formas. Atklāts ir jautājums par to, cik labiekārtota pludmale ir pārējos gadalaikos, ne tikai vasarā. Arī ruden̄̄ un ziemā cilvēki nereti atpūšas pie ūdens un cel̦o. Tātad tādām elementārām lietām kā labierīcības vajadzētu būt pieejamām visu gadu, neatkarīgi no sezonas un laika apstākḷiem.

Tika izveidota aptauja, ar mērķi noskaidrot iedzīvotāju viedokli par esošo situāciju piekrastes būvju jomā, uzzināt aktuālākās problēmas, trūkumus, stiprās un vājās puses, kā arī saņemt ieteikumus par piekrastes vides uzlabošanu. Veidojot aptauju izmantoti atklātie un slēgtie jautājumi, kā arī tiešie un netiešie jautājumi, ievērota aptaujas struktūra (3). Aptauja tika publicēta tiešsaistēe, kā arī nosūtīta elektroniski Latvijas piekrastes pašvaldībām, kā arī Rīgas Tehniskās universitātes pasniedzējiem un izdalīta studentiem 2015. gada vasarā un ruden̄i. Kopumā tika aptaujāti 112 respondenti.
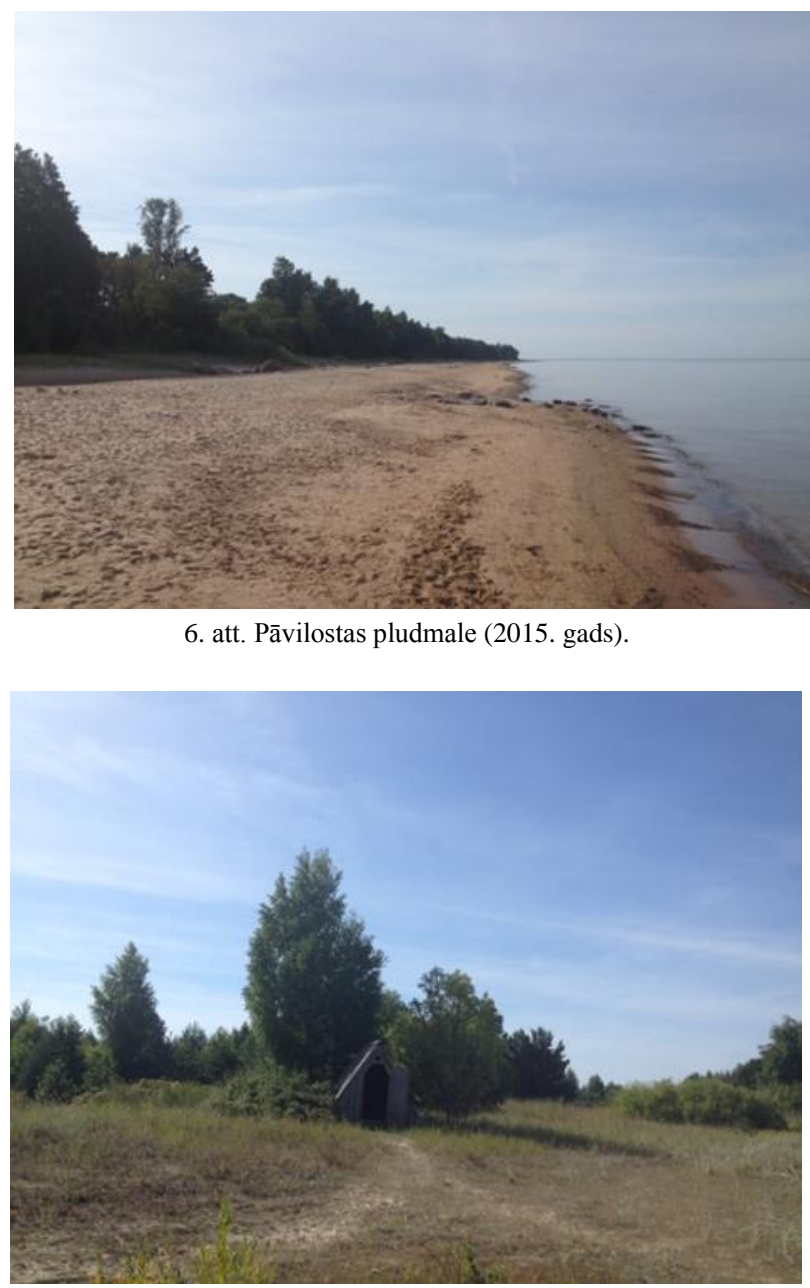

7. att. Randu pḷavas Ainažos, aptuveni 200 m no jūras (2015. gads). 


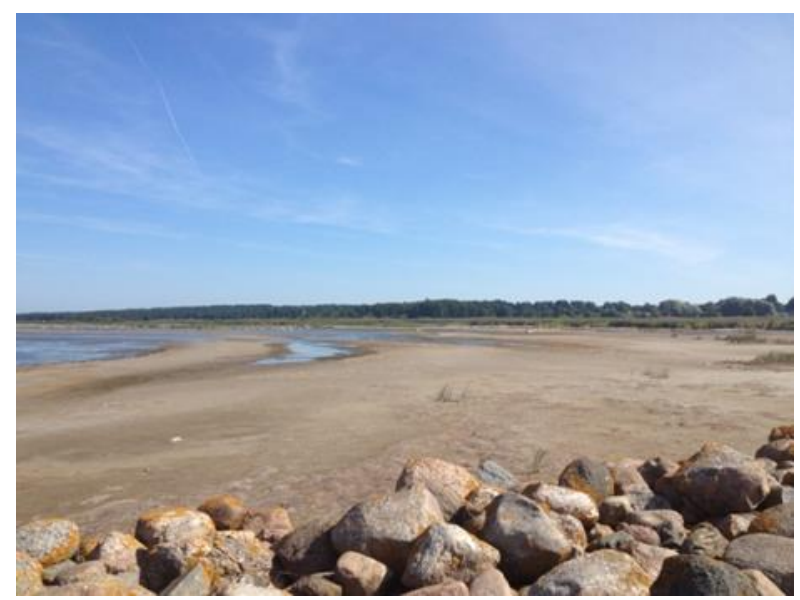

8. att. Ainažu pludmale (2015. gads).

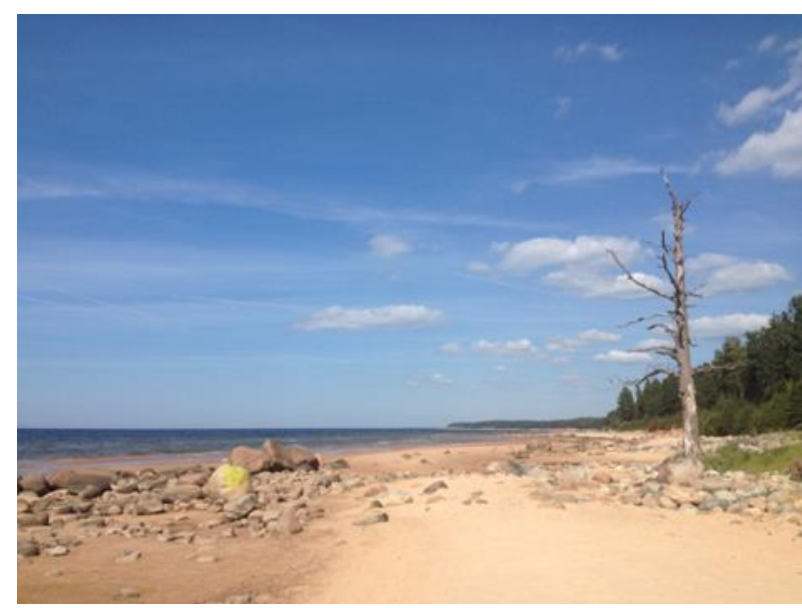

9. att. Liepupes pludmale (2015. gads).

Vai Jūsuprāt piekrastes zonā ir izvietots pietiekams daudzums geērbtuvju, dušas telpu, labierīcību?

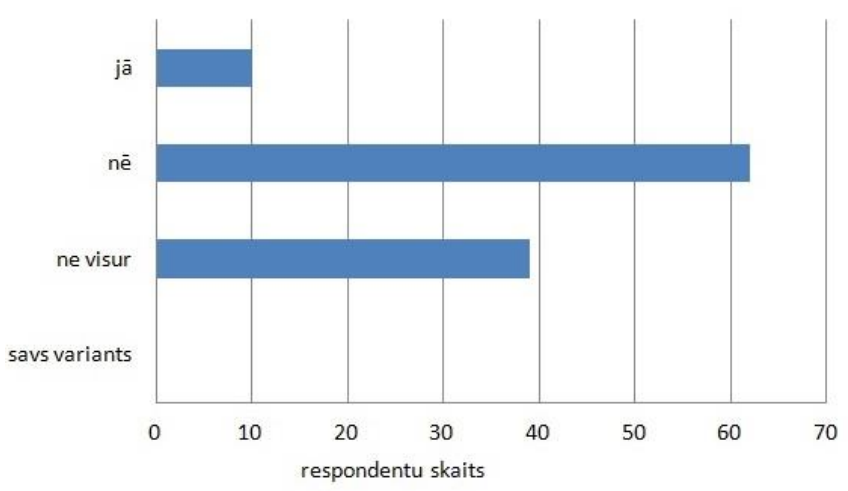

10. att. respondentu atbildes par labierīcību daudzumu piekrastes zonā.

Lielākā daļa respondentu (56\%) uzskata, ka piekrastes zonā nav pietiekams daudzums gèerbtuvju, labierīcību, tomēr $35 \%$ aptaujāto respondentu uzskata, ka ir atsevišksas teritorijas, kur šādu būvju ir pietiekami daudz (skat. 10. attēlu). No šiem datiem var secināt, ka aptaujātie iedzīvotāji saskata šajā jomā būtiskus trūkumus un ka respondenti ir apmeklējuši dažādas piekrastes dažādās teritorijās. Pavisam neliels procents aptaujāto - 9 \% uzskata, ka ar piekrastes būvēm viss ir kārtībā un tās ir pietiekamā daudzumā. Šie aptaujātie, iespējams, dzīvo kādā no lielākajām piekrastes pašvaldībām, jo kā tika novērots apsekošanā, lielākajās piekrastes pašvaldībās piekrastes būves ir krietni lielākā skaitā, nekā mazajos pagastos.

Vai Jūsu apmeklētajās piekrastes zonas būvēs bija pieejams siltais ūdens?

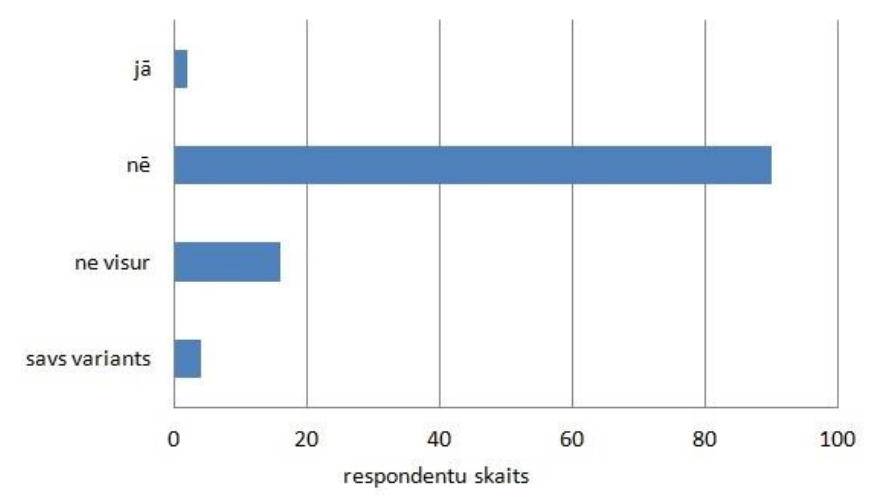

11. att. Respondentu atbildes par siltā ūdens pieejamību piekrastes zonas būvēs.

11. attēēā redzams, ka $80 \%$ no respondentiem nav saskārušies ar ūdens uzsildīšanu piekrastes būvēs. Šie dati apstiprina nepieciešamību pēc silta ūdens piekrastes būvēs. Siltais ūdens ir būtiska labierīcību sastāvdaḷa - roku mazgāšanai vai dušai, īpaši tas ir būtiski gimenēm ar maziem bērniem un sportistiem.

Vai Jūsuprāt piekrastē būtu nepieciešama būve ar iespēju šo būvi izmantot visos gadalaikos un arī ārpus piekrastes zonas?

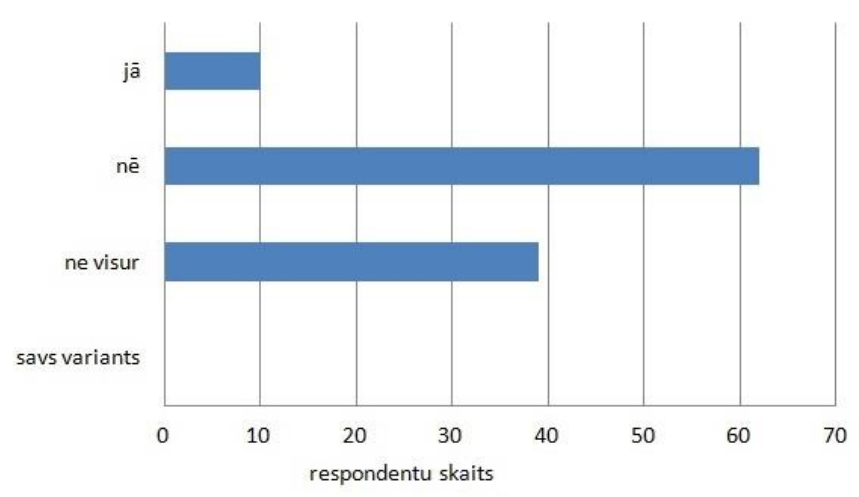

12. att. respondentu atbildes par daudzfunkcionālas būves izvietojumu piekrastes zonā, ar funkciju izmantot tās visu gadu.

Bieži laika apstākḷi nav patīkami un tad silts ūdens dušā ir pirmās nepieciešamības lieta. $14 \%$ respondentu siltais ūdens ir bijis pieejams atsevišksās vietās, savukārt pie iespējas pierakstît savu atbildi, respondenti ir rakstījuši, ka ūdenim dušās un vietās, kur nomazgāt rokas vajadzētu būt vismaz remdenam, katrā zin̄ā ne ledainam (skat. 11. att.).

12. attēls parāda, ka $62 \%$ aptaujāto respondentu saskata reālu iespēju piekrastes zonā izvietot daudzfunkcionālu būvi, kuru varētu izmantot visa gada garumā arī ārpus piekrastes zonas. 33 \% aptaujāto uzskata, ka šāda būve ne visās teritorijās 
būtu izmantojama ārpus piekrastes zonas. Neliels skaits (5\%) aptaujāto uzskata, ka piekrastes būve nav jāizmanto ārpus pludmales. Iespējams, šie respondenti nekad nav dzirdējuši par modulārām, pārvietojamām būvēm, tāpēc nesaredz šādu iespēju.

No kādiem materiāliem jūs gribētu redzēt jaunās piekrastes būves sezonas aktivitātēm:

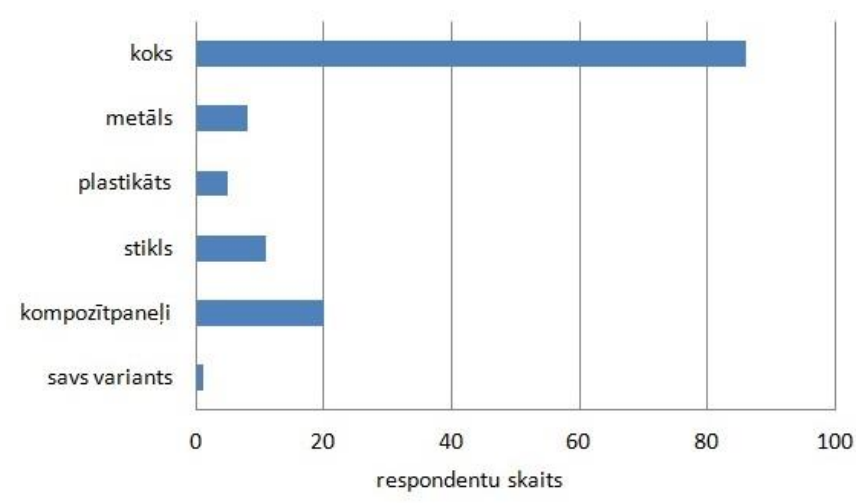

13. att. Par respondentu atbildēm no kādiem materiāliem būvētai vajadzētu būt piekrastes būvei.

13. attēls parāda, ka viennozīmīga priekšroka tiek dota dabīgajam materiālam - kokam. Brīvajās atbildēs koks tiek atzīts kā materiāls, kurš iederas apkārtējā vidē, kas tiek minēts kā būtisks faktors piekrastes būves dizainā. Koku izvēlēts papildināt gan ar stiklu, gan metālu. Kompozītpanel̦us kā variantu ir izvēlējušies $15 \%$ respondentu. Kompozītpanel̦i ir "jaunās paaudzes" materiāls, kurš paredz koksnes kombināciju ar citiem materiāliem. Koksnes kompozītmateriāli l̦auj taupīt un racionāli izmantot meža resursus, būtiski samazinot patērējamās lietkoksnes daudzumu. Kompozītmateriālu veido koksnes daļiņas un termoplastiskie polimēri: polietilēns, polipropilēns, polistirols, poliamīds u.c. (4).

Apkopojot iegūtos aptaujas rezultātus, var secināt, ka lielākā daḷa aptaujāto respondentu vēlas nākotnē redzēt uzlabojumus piekrastes zonā. Galvenais vadmotīvs ir vienotība. Jābūt vienotam dizainam, kas veidotu atpazīstamību jebkurā piekrastes pašvald̄̄bā, ne tikai Latvijā. Būvei jābūt tādai, kas iekḷaujas apkārtējā vidē - tādai, kas nav uzbāzīga, ir būvēta no ekologíiskiem, reizē ar̄̄ noturīgiem materiāliem. Būvei jābūt ilglaicīgai, tādai, kas ir funkcionāla un saprotama (5).

\section{ENERGOEFEKTIVITĀTE}

Lai piekrastes būves varētu būt energoefektīvi apkalpojamas, tās varētu aprīkot ar mūsdienīgu inženiertehnisko sistēmu. Saules panel̦i un saules kolektori dod iespēju taupīt elektroenerǵiju: saules paneļu uzkrāto enerǵiju izmanto telpu apgaismošanai, savukārt saules kolektoru uzkrāto enerǵiju izmanto aukstā ūdens uzsildīšanai. Saules bateriju sistēmas iedalās 3 kategorijās:

- pie elektrotīkla pieslēdzama sistēma - darbojas tikai tad, ja ir spriegums no tīkla;

- autonomā sistēma - paredzēta vietām, kur nav tīkla pieslēguma - lauku mājas, vasarnīcas (skat. 14. attēlu);
- kombinētā sistēma - darbojas gan kopā ar tīkla pieslēgumu, gan bez. Īpaši interesēs tos reǵionus, kur ir regulāri strāvas padeves pārrāvumi (skat. 15. att.).

\section{A. Autonomā sistēma}

Tuvāk apskatot katru no sistēmām, par vispiemērotāko piekrastes zonai tiek atzītas autonomās sistēmas. Šīs sistēmas piemērotas vietās, kur elektrotīkls nav pieejams. Autonomās saules bateriju sistēmas darbojas ar akumulatora palīdzību, saražotā elektroenerğija tiek uzkrāta akumulatorā un izlietota kad nepieciešama, atkarībā no akumulatora darbības ilguma.

Autonomā sistēma (skat. 14. att.) vislabāk darbojas no pavasara sākuma līdz oktobrim, kad tiek saņemts visvairāk saules gaismas. Jāṇem vērā, ka Latvijas apstākļos, lai nodrošinātu nepārtrauktu elektroapgādi, ir nepieciešams alternatīvs elektroenerğijas avots, piemēram, ar degvielu darbināms strāvas ǵenerators (6).

\section{B. Kombinētā sistèma}

Veidojot projektu daudzfunkcionālai būvei, tiek piedāvāts alternatīvs jeb papildus risinājums vietās, kur ir pieejama elektroenerǵija un vietās kur nepieciešams izmantot enerǵiju ilgākā laika posmā. Kombinētās sistēmas (arī hibrīd-sistēmas) sastāv no elektrotīklam pieslēdzamas un autonomas sistēmas kombinācijas. Diennakts gaišajā laikā saražotā enerǵija tiek lietota pašpatērinsam, kā arī novadīta akumulatora lādēšanai. Diennakts tumšajā laikā mājsaimniecība izmanto akumulatorā uzkrāto enerǵiju. Iztrūkstošā elektroenerǵija tiek saņemta no elektrotīkla, bet pārpalikums - pārdots elektrotīklā, izmantojot NETO uzskaites priekšrocības (skat. 15. attēlu).

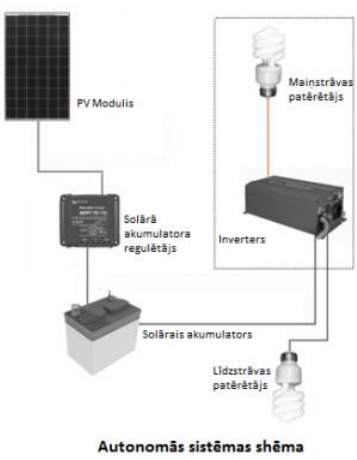

14 .att. Autonoma sistēma.

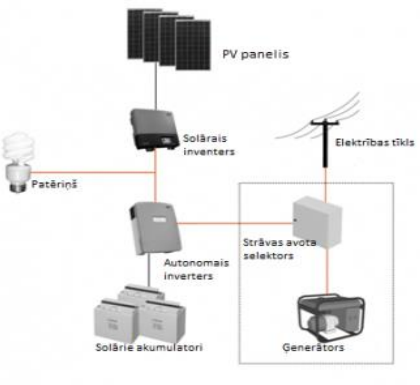

Kombinêtã̃s sistēmas shểma
15. att. Kombinētas sistēmas shēma.

\section{VADLĪNIJAS PIEKRASTES BŪVJU DIZAINĀ}

Darba procesā tika iepazīts Elīnas Teteres maǵistra darbs "Mūsdienīgu sabiedrisko labierīcību ieviešana Baltijas jūras piekrastē Kurzemē" (2011), kurā apskatīta labierīcību problēma - trūkums, neesamība un nolietotība (7). Iepazītajā maǵistra darbā likts uzsvars uz vienotu sabiedrisko labierīcību dizaina ieviešanu, kas sakārtotu vidi un padarītu sabiedriskās labierīî̄bas pieejamas ikkatram - gan vietējiem iedzīvotajiem, gan iebraucējiem (7)

Kristiāna Pavasare savā maǵistra darbā "Vides objekti kā vienota informācijas stendu un norāžu sistēma Baltijas jūras piekrastē" (2011) arī uzsver vienotas sistēmas svarīgumu 
apkārtējā vidē. Vienota shēma, vienots dizains sakārto un rada atpazīstamību (8).

Laba dizaina pamatprincipi veido sistēmu, pēc kuras vadīties, veidojot jaunu dizaina objektu.

Labs dizains ir inovatīvs - inovatīvs dizains attīstās tādā pašā līmen̄i kā inovatīvas tehnolog̣ijas (5).

Izmantojot tehnologijiju attīstību, rodas iespējas pielāgot tās un iekl̦aut dažādos dizaina objektos, padarot tos izturīgākus, energoefektīvākus un mūsdien̄̄gākus.

Labs dizains rada lietojamu produktu. Labs dizains uzlabo produkta lietojamību un praktisko vērtību (5).

Funkcionalitāte ir būtisks faktors jebkurā dizaina objektā. Par funkcionalitāti vairāk runā saistībā ar sabiedriskām būvēm un objektiem. Būvei jābūt ērtai lietošanā un piemērotai ikvienam lietotājam.

Labs dizains ir tik maz, cik iespējams. Tīrība un vienkārš̄îba (5).

Labs dizains ir estētisks Produkta estētiskā kvalitāte ir būtiska lietojamības daḷa (5).

Estētiskums ir viena no būtiskākajām sastāvdaḷām veiksmīgā sabiedriskā būvē vai objektā. Tas, cik vizuāli estētisks ir objekts, nosaka to vai cilvēki to lietos.

Labs dizains veido produktu saprotamu. Tas precizē produkta struktūru un tas ir pašizskaidrojošs (5).

Labs dizains ir godīgs, tas nemēgina manipulēt ar klientu solījumiem, ko tas nepilda.

Labs dizains ir neuzbāzīgs. Produkti, kas sasniedz mērḳi ir kā instrumenti; to formai jābūt neitrālai, lai atstātu telpu lietotāja pašizteiksmei.

Labs dizains ir ilgstošs un valstiska mēroga. Tas izvairās būt moderns, tas saglabājas gadiem, pat mūsdienu paātrinātajā sabiedrībā (5).

Ilgtspējība ir faktors, kas jāņem vērā, veidojot sabiedriskās būves projektus. Sabiedriskās būves lieto liels cilvēku skaits katru dienu, tāpēc izvēlētajām tehnologijijām un materiāliem ir jābūt pietiekami noturīgiem, lai kalpotu ilgus gadus un nenolietotos. Ieguldot līdzekḷus, ir nozīmīgāk ieguldīt tos ilgtspējīgā projektā, jo tas kalpos daudz ilgāku laika posmu un nebūs periodiski jāatjauno.

Labs dizains ir pamatīgs līdz pēdējai detaḷai, nekas nav gadījuma pēc.

Labs dizains ir videi draudzīgs, tas saglabā dabas resursus un samazina fizisko un vizuālo piesārṇojumu visā produktu dz̄ives ciklā (5).

Mūsdienās ne katrs jaunais dizaina objekts, lai tā būtu èka, vai mēbele, atbilst minētajiem laba dizaina principiem. Tomēr katrā no mūsdienu jaunajiem dizaineru darbiem mēs varam atrast kādu no šiem dizaina principiem. Reti kurš veido jaunu dizainu, balstoties uz šiem principiem. Jaunais top bieži vien spontāni, un nereti tas ir veiksmīgs jauninājums.

\section{SECINĀJUMI}

Ir apkopota informācija par Latvijas jūras piekrastes zonā izvietotajām labierīcībām, atpūtas būvēm un objektiem. Tika apsekota esošā situācija, apmeklējot 17 Latvijas piekrastes pašvaldības. Tika izveidota aptauja, ar mērksi noskaidrot problēmas aktualitāti, uzzināt iedzīvotāju viedokli un saṇemt ieteikumus piekrastes joslas būvju un objektu nepieciešamībai, dizainam un tehnoloǵiskajiem risinājumiem.

Ir jāizveido vienota sistēma, jo apkopojot visus iegūtos datus un izpētot esošo situāciju, var secināt, ka piekrastes zona Latvijā ir nesakārtota, trūkst vienotas sistēmas, kura veicinātu atpazīstamību un sakārtotu vidi piekrastes joslās, protams, ņemot vēra aizsargjoslu likumu.

Piekrastes būves analizētas pēc laba dizaina nosacījumiem, kuriem tām vajadzētu atbilst un veidojot piekrastes būves projektu, tas būtu veidojams, ievērojot šos laba dizaina principus.

Aptaujātie respondenti atzīst, ka problēma pastāv, tā ir jārisina. Respondentu ieteikumi bija svarīgi, tādā veidā sekmējot maǵistra darba procesu un pētījumu tālāku virzību. Iepazīstoties ar aptaujas rezultātiem, rodas secinājumi, ka ir nepieciešams izvietot piekrastes būves, kurās būtu silts vai vismaz remdens ūdens, piekrastes būvēm jāiekḷaujas apkārtējā vidē - šo faktoru uzsver lielākā daļa aptaujāto. Par svarīgu objektu tika izvirzīts ūdens tornis, kurš dotu iespēju noskalot kājas, izkāpjot ārā no smiltīm. Aptaujātie atzīst, ka būvēm jābūt veidotām no dabīgiem materiāliem, no piedāvātajiem variantiem, priekšroka dota kokam. Ilgtspējība tika atzīta par l̦oti nozīmīgu, kā arī uzsvērta tīrības un sakoptības problēma esošajās piekrastes būvēs un objektos. Būvēm jābūt saprotamām, ērtām lietošanā un pieejamām ikvienam.

Šobrīd tiek strādāts pie būves funkcionālajiem risinājumiem, lai tos apvienotu vienā būvē, top skices un meklēti piemērotākie tehniskie risinājumi, kā arī meklēts atbalsts no piekrastes pašvaldībām un sadarbības iespējas ar arhitektiem.

Attīstoties projektam, iespējams tiks piedāvātas izstrādes arī dažādām mazajām arhitektūras formām, kuras būtu piemērotas piekrastes joslai, piemēram, solini, apgaismojums, atpūtas vietas ar nojumēm u.c.. Šis kopums l̦aus sakārtot piekrastes joslu visā Latvijas teritorijāa, veidojot to vienotu, estētisku un pieejamu ikvienam.

\section{LITERATŪRAS SARAKSTS}

1. Latvijas valsts robežas. [Tiešsaiste]. [Skatīts: Sept. 25, 2015]. Pieejams: http://www.letonika.lv/groups/?title=Latvijas\%20valsts\%20robe\%C5\% BEas/32489.

2. Aizsargjoslu likums. [Tiešsaiste]. [Skatīts: Sept. 25, 2015]. Pieejams: http://likumi.lv/doc.php?id=42348.

3. Kristapsone, S. Zinātniskā pētniecība studiju procesā. Rīga: SIA Biznesa augstskola Turība, 2008, 225.-270. lpp.

4. Ziemelis, A. Jaunie kompozītmateriāli. Rīga: RTU, 2009, 3.-5. lpp.

5. Gudro, I. Laba dizaina principi, lekciju konspekti. Rīga: RTU, 2014

6. Saules baterijas. [Tiešsaiste]. [Skatîts: Sept. 25, 2015].Pieejams: http://solenergo.lv/saules -baterijas/saules - bateriju - sistemas.

7. Tetere, E. Mūsdien̄̄gu sabiedrisko labierīcību ieviešana Baltijas jūras piekrastē Kurzemē. Rīga: 2011, 1. - 11. 39. - 41.-70. lpp.

8. Ulme A., Pavasare, K. Vides objekti kā vienota informācijas stendu un norāžu sistēma Baltijas jūras piekrastē, RTU Zinātniskie raksti. ,Materiālzinatne," no. 5, 2010, 117.-122. lpp. 


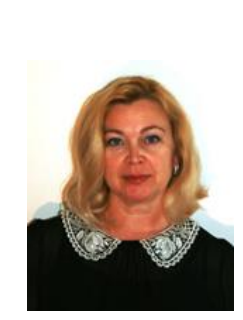

Andra Ulme, Dr. arch., Associated Professor, Riga Technical University, Faculty of Materials Science and Applied Chemistry, Institute of Material Technology and Design. Work experience: interior designer, interior architect, specializing in public and private interiors, specializing in hotel interior design, more than 15 projects in suburbs over the last ten years completed, mostly in luxury style. Scientific activities: exploration of unutilized hidden resources and research of utilization possibility of such resources to promote the development of national economy of Latvia.

Address: Institute of Design Technologies, Riga Technical University, Kipsalas Str. 6, Riga, LV-1048, Latvia.

E-mail: andra.ulme@rtu.lv

Phone: +371 67089256

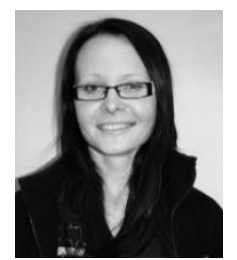

Evita Bārbale, Bac. Inter. (since 2014 a MA programme student), Riga Technical University, Faculty of Materials Science and Applied Chemistry, Institute of Material Technology and Design. Work experience: interior design, product design.

Address: Institute of Design Technologies, Riga Technical University, Kipsalas Str. 6, Riga, LV1048, Latvia.

E-mail: evita.barbale@gmail.com Phone +371 26427103

\section{Andra Ulme, Evita Barbale. Multifunctional, Modular and Sustainable Construction in the Coastal Area}

The aim of this article is to explore the current situation on the sea coast of Latvia, coastal buildings and objects. Coastal zone is one of the places where constructions and buildings with simple functions should be situated, for example, shower, toilet and relaxation space. In this article the term "coastal zone" corresponds to the definition used in the Law on Protective Zones. By using natural, ecological and energo-effective materials and constructions, it is possible to save energy and conserve the environment. Public opinion on the need to make changes in Latvian coastal area was ascertained using a poll open to local and all other interested respondents. It is displayed with the help of diagrams. Consideration is given to examples of global environmental objects, analysis of the principles of good design and sustainable development. The key conclusion is that good design needs functionality. General guidelines for coastal constructions and buildings with primitive functions (toilets and showers) in coastal zone of Latvia were developed within the framework of this work.

\section{Андра Улме, Эвита Барбале. Многофункциональные, модульные и долгосрочные сооружения в прибрежной зоне}

Целью настоящего исследования является изучение текущей ситуации в сфере прибрежных сооружений и объектов на морском побережье Латвии. Прибрежная зона является одним из мест, где должны быть конструкции и здания с простыми функциями, например, душ, туалет, места для отдыха. В настоящей статье термин «прибрежная зона» соответствует определению, используемому в Законе о сохранении зон побережья. Использование природных, экологических и энергоэффективных материалов и конструкций создаёт возможность экономии энергии и сохранения окружающей среды. Опрос местных и всех заинтересованных респондентов дал возможность выяснить общественное мнение о необходимости изменений в прибрежной зоне на территории Латвии. Результаты опроса отображены на диаграммах. Особое внимание уделено глобальным экологическим объектам, анализу принципов функционального дизайна и устойчивого развития. Ключевой вывод - качественный дизайн и функциональность. В рамках этой работы были разработаны общие рекомендации для строительства прибрежных сооружений и зданий в местах для отдыха в прибрежной зоне на территории Латвии. 